\title{
ФОРМИРОВАНИЕ И РЕАЛИЗАЦИЯ ЭКОЛОГИЧЕСКОЙ ПОЛИТИКИ РОССИЙСКОЙ ФЕДЕРАЦИИ ЧЕРЕЗ ПРИЗМУ ЭКОНОМИЧЕСКОЙ СОСТАВЛЯЮЩЕЙ
}

\author{
(c) 2020 Наумова Татьяна Максимовна
}

кандидат экономических наук, доцент Кафедры финансов экономики и организации производства Поволжский государственный технологический университет, Россия, Йошкар-Ола

E-mail: MalkovaTM@volgatech.net

(c) 2020 Шлычков Дмитрий Сергеевич

кандидат экономических наук, доцент Департамента учета, анализа и аудита

Финансовый университет при Правительстве Российской Федерации, Россия, Москва

E-mail: sds457@mail.ru

Формирование эффективной экологической политики является приоритетным направлением развития современного государства. В настоящее время экологическая политика в России реализуется с низкой эффективностью. Решение проблемы предполагает постановку стратегических и тактических целей и их осуществления путем реализации краткосрочных, среднесрочных и долгосрочных программ, гарантированных мер по обеспечению экономики природными ресурсами и поддержанию благоприятных условий жизни населения, требований экологической безопасности и устойчивого развития. Последнее является основным условием обеспечения баланса экологии и экономики.

Основным результатом исследования проблем экологической политики России и ее влияния на экономику в том числе в части экологического налогообложения является баланс между влиянием общества на экологию посредством использования в производственном процессе и взимание налогов и сборов на восстановление экологического баланса.

Ключевые слова: экология, налогообложение, экологическая политика, экономика природопользования, экологические платежи.

Экологическая политика - это сознательная и организованная регулирующая деятельность, с помощью которой при посредничестве государства и общественных организаций регулируется отношение общества к природе с целью защиты и развития окружающей среды. Экономическими инструментами для реализации экологической политики являются налоги (пошлины на выбросы, дифференциация налогообложения в зависимости, например, от использования ресурсосберегающих технологий, налоговые льготы), преимущества с точки зрения финансовой и инвестиционной политики (субвенции субъектам предпринимательской деятельности для реализации природоохранных мероприятий, например, для сокращения выбросов, выдача кредитов на льготных условиях), создание рынков права на загрязнение (экологическая маркировка, утилизация отходов, экологическое страхование), заключение контрактов.

Люди не могут избежать грязного возду- ха, который проникает повсюду, - ни внутри дома, ни за его пределами. А залогом здоровья и долголетия человека является именно чистый воздух. К сожалению, в современном мире достижение этого фактора кажется практически невозможным.

Загрязнение окружающей среды подразделяется на антропогенное и естественное загрязнение. Антропогенные источники, связанные с деятельностью человека, больше всего загрязняют воздушную среду. Природные источники, загрязняющие воздушную среду, незначительны и восстанавливаются самой природой.

Промышленное загрязнение стоит на первом месте по загрязнению воздуха. Львиная доля приходится на предприятия энергетики, металлургии. Далее следуют нефтепереработка, машиностроение и химическая промышленность. В промышленных зонах в атмосфере наблюдается повышенное содержание углеводородов, ртути, свинца, диоксида серы, тяжелых 
металлов.

Загрязнение от удобств современного мира - транспорта, который является удобным средством передвижения, - является основной угрозой здоровью человека. Автомобиль поглощает кислород из атмосферы, выделяет углекислый газ и токсичные вещества углеводородов. В среднем один автомобиль выделяет 135 кг окиси углерода и 25 кг окиси азота в год. Если рассматривать объемы загрязнения по отраслям, то 85\% загрязнений происходит в легковых и грузовых автомобилях, 5\% для речного и морского транспорта, 7,5\% воздуха и железнодорожных, 2,5\% сельскохозяйственной техники.

В 2012 году приняты «Основы государственной политики в области экологического развития Российской Федерации на период до 2030 года» (утв. Президентом РФ 30.04.2012). На данном документе основана вся экологическая политика страны, которая направлена на усовершенствование нормативно-правовой базы, обеспечение экологически ориентированного роста экономики и внедрение экологически эффективных инновационных технологий. Также документ призывает к максимальному воздействию на окружающую среду, принятию исчерпывающих мер к восстановлению нарушенных естественных экосистем, сохранению объектов животного и растительного мира, обеспечению экологически безопасного обращения с отходами. Остро стоит вопрос развития регулирования и рыночных инструментов охраны окружающей среды и обеспечения экологической безопасности.

Анализ международных источников экологического права показал, что выделяют источники, являющиеся носителями действующих правовых принципов и норм и образующие право, и источники, которые содержат необязательные или рекомендательные правила. К первой группе относят международные конвенции, соглашения, договоры, резолюции некоторых международных организаций, международные обычаи и судебные решения. Здесь ведущую роль относят к конвенциям. В настоящее время ведется их учет и ежегодная публикация их списка с содержанием. Международные договоры имеют политическое содержание (касаются вопросов мира, безопасности, сокращения вооружений) и экологическое содержание (касаются вопросов природопользования и охраны окружающей среды). Договоры экологического содержания имеют эколого-комплексную направленность (Конвенция о запрещении военного или любого иного враждебного использования средств воздействия на природную среду; Конвенция о трансграничном загрязнении воздуха на большие расстояния и др.) либо эколого-ресурсную направленность (документы, касающиеся, например, регулирования рыболовства, международно-правового режима пограничных морей и пр.).

Согласно Конституции РФ, по предметам совместного ведения, к которым относится охрана окружающей среды, природопользование и обеспечение экологической безопасности, должны издаваться федеральные законы и принимаемые в соответствии с ними законы и иные нормативные акты субъектов Федерации. Основными законодательными актами по охране природы в нашей стране являются законы России «Об охране окружающей природной среды», Земельный кодекс РФ, «О недрах», Лесной кодекс РФ, Водный кодекс РФ.

В России уязвимая окружающая среда, и в результате антропогенного давления способность природной среды обеспечивать будущее экономическое и социальное развитие была нарушена почти по всей стране. Получается, что в настоящее время ограниченный характер природных благ становится критическим фактором, сдерживающим возможность дальнейшего прогресса не только в промышленности, но и во всей социально-экономической системе России. Таким образом, своевременное исследование и теоретическое развитие финансовых экологических проблем необходимы.

В своей работе авторы Н.Н. Лукьянчиков, И.М. Потравный определили «понятийный аппарат экономики природопользования в рамках развития теории естественного капитала расширился такими понятиями, как «глобальные экологические услуги», «экологический донор», «компенсационные выплаты в целях сохранения экосистемы» и др. Говоря о существовании дополнительных расходов отдельных территорий на сохранение и восстановление природного комплекса, а также потерь, которые несут многие регионы в условиях особого режима природопользования, необходимо отметить также существование определенных выгод, которые имеют место в условиях ограниченного природопользования. В этих условиях Еханурова Е.А. предлагает ввести новую категорию экономики 
природопользования - «экологические выгоды», которая определяется как совокупность доходов (прямых и косвенных), получаемых от использования природных благ территории с особым режимом природопользования. Одновременно предлагается ввести понятие «экологический выгодоприобретатель», под которым понимается субъект экономики (конкретное предприятие, отрасль хозяйства, человек, предприниматель, регион, страна в целом, мировое сообщество), который получает прямой или косвенный доход от использования природных благ территории с особым режимом природопользования. С этой точки зрения экологические выгоды в структуре экономических активов национального богатства страны представлены следующим образом (рис. 1)». [5]

Как известно, устойчивое развитие базируется на экономической, социальной и экологических компонентах. Ориентиром устойчивого развития служит баланс всех трех элементов. Суть новой парадигмы развития всей мировой цивилизации - переход к обществу высокой нравственности, качества жизни и устойчивого развития (человечества, природы и техносферы). Сторонниками данной парадигмы являются общественные деятели, экономисты и финансисты, а также действующие предприниматели. Стоит отметить, что в 1972 г., во время проведения Стокгольмской конференции по окру- жающей среде, участники высказали озабоченность проблемами экологической обстановки ведущие мировые производители. Экономисты и финансисты же высказали мнение, что многие виды деятельности неустойчивы в долгосрочном плане, и поэтому финансовый рынок является силой, поддерживающей устойчивый прогресс человечества, поэтому поощряются и краткосрочные виды деятельности, направленные на извлечение прибыли, но вопросы экологической безопасности не должны оставаться в стороне.

Экологическая политика должна рассматриваться в тандеме с другими сферами (с экономической политикой, социальной и пр.). Также она должна быть совместима с принципами рыночной политики и решать такие вопросы как конкурентоспособность продукции, структура рынка, ценообразование, рыночное равновесие, что обеспечивает сбалансированность экономики.

Несовершенство российского законодательства в области охраны и защиты окружающей среды, систем налогообложения, природоресурсного законодательства не обеспечивает эффективный механизм реализации экологической политики. Результатом является развитие промышленного производства без ориентации на экологическую безопасность, негативное воздействие на окружающую среду, усиление загрязняющего воздействия на атмосферный

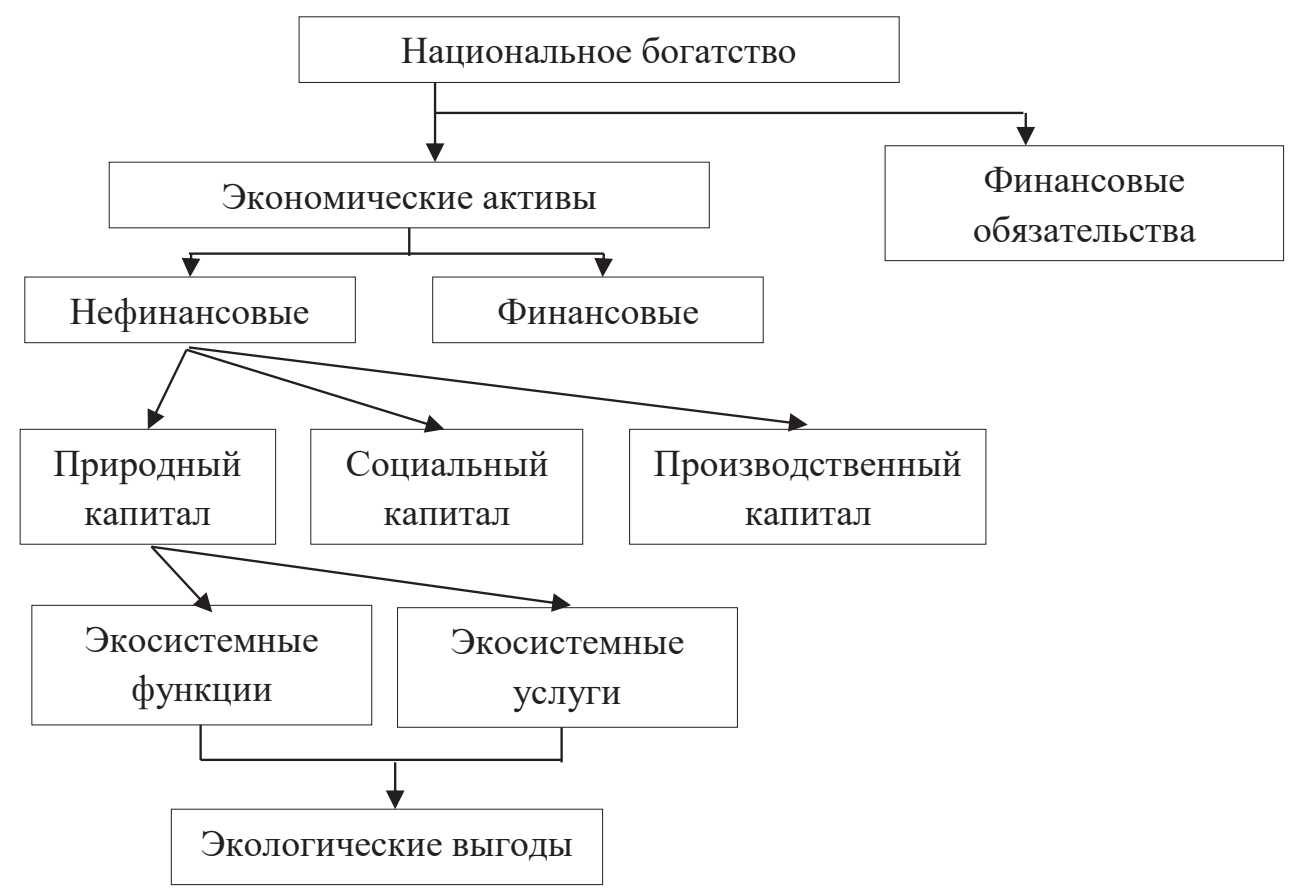

Рисунок 1. Взаимосвязь экологических выгод и национального богатства страны. 
воздух, водные ресурсы и территории. Размеры экологических платежей, взимаемых за негативное воздействие на окружающую среду, являются недостаточными для финансирования государственных целевых программ в области природопользования и для стимулирования применения в производстве экологически безопасных технологий.

В чистом виде экологический налог в Российской Федерации не является юридической категорией, не закреплен в каких-либо источниках права. По мнению некоторых экспертов, экологический налог в будущем будет в дополнение транспортного налога (утвержденный главой 28 НК РФ). В Правительстве Российской Федерации рассматривают предложения по утверждению норм, позволяющих уплачивать налог с владельцев транспортных средств, исходя из их экологических характеристик (например, не соответствие стандартам ЕВРО). Экологический налог предлагается начислять исходя из взаимосвязи с интенсивностью загрязнения окружающей среды и определенным видом автотранспортного средства. При этом введение такого налога санирует с рынка машины устаревших моделей, что в конечном итоге стимулирует приобретение новых автомобилей, в том числе отечественного производства.

Между терминами «экологический налог» и «экологический сбор» есть основные различия:

- экологический налог предполагает регулирование посредством положений НК РФ, экологический сбор - общим налоговым законодательством, а также подзаконными правовыми актами (постановлениями Правительства РФ);

- экологический налог относится к налоговым доходам бюджета, а экологический сбор неналоговый сбор;

- налоговые поступления в бюджеты расходуются на различные цели, когда как экологический сбор должен использоваться в конкретных целях

Минфином разработан проект изменений в Налоговый кодекс, который предусматривает введение экологического налога как для физических, так и для юридических лиц, в том числе индивидуальных предпринимателей.

По сути экологический налог должен заменить действующие платежи за выбросы загрязняющих веществ в атмосферный воздух, сбросы загрязняющих веществ в составе сточных вод в водные объекты, осуществляемые в пределах нормативов допустимых выбросов, нормативов допустимых сбросов, за размещение отходов производства и потребления в пределах установленных лимитов на их размещение.

Данное нововведение должно повысить экологическую эффективность, так как за невнимательность к решению экологических вопросов предприятия и организации будут нести дополнительных расходы. А внедрение ресурсосберегающих технологий или технологий, способствующих повышению экологической эффективности, позволят снизить производителям дополнительные расходы (экологический налог). Некоторым предприятиям придется ввести в штат специалиста в сфере экологии или воспользоваться консалтинговыми услугами в данной области, работа которых позволит снизить налоговую ставку по экологическому налогу.

«Природоэксплуатирующие сектора в экономике России занимают от 25 до 30\% ВНП, а их доля в доходах консолидированного бюджета РФ составляет около 7-8\%» [11].

Анализируя налоговый потенциал, можно сделать вывод, что максимально возможный уровень доли поступлений доходов от эксплуатации природных ресурсов, обеспечиваемый налоговой системой в целом (включая прямые и косвенные налоги), не может превысить $20 \%$. Это подтверждает необходимость осуществления реформ в налоговой системе РФ.

Кроме пополнения бюджета и реализации программ по охране и воспроизводству природных ресурсов налоговые средства должны использоваться на следующие мероприятия: ведение кадастра природных ресурсов, проведение экологического и природно-ресурсного мониторинга, картографирование, социальноэкономическую оценку природных ресурсов, выполнение необходимых научно-исследовательских работ и проектных разработок, финансирование соответствующих организационных структур природно-ресурсного блока, проведение специальных обследований и изысканий, разработку природоохранных нормативов и стандартов (а также другие мероприятия).

Деятельность любого промышленного предприятия так или иначе наносит вред окружающей среде, связанный со сбросом загрязняющих веществ в водные ресурсы, их выбросом в воздух, ионизирующими или электромагнитными воздействиями. Именно поэтому отечественным 
законодательством предусмотрены так называемые экологические платежи, представляющие собой денежную компенсацию, рассчитываемую с учетом особенностей той или иной организации. В качестве обоснования для расчета экологических платежей используются Федеральные законы «Об отходах производства», «Об охране окружающей среды» и «Об охране атмосферного воздуха». Кроме того, для этой цели используются постановления Правительства РФ, которые вносят уточнения и дополнения в вышеперечисленные нормативные акты. Экологические платежи - это компенсация, выплачиваемая предприятиями лишь за следующие виды воздействия: сброс веществ, негативно влияющих на экологическую обстановку местности, в поверхностные водоемы; атмосферные выбросы, загрязняющие воздух; утилизация опасных отходов производства той или иной продукции, a также ее потребления. Важным фактором, имеющим огромное значение при расчете экологических платежей предприятия, является наличие следующей документации: проект предельно допустимых сбросов загрязняющих веществ; проект лимитов образования отходов и их утилизации; проект выбросов загрязняющих веществ в атмосферный воздух. Наличие этих документов говорит о том, что предприятие осуществляет свою деятельность в полном соответствии с действующим законодательством, стремится всеми силами снизить негативное воздействие на окружающую среду и готово производить оплату экологических платежей в требуемом объеме. Если организация не оформляет ПДВ и НДС, плата за негативное воздействие на окружающую среду составит в 25 раз больше, чем с наличием этих проектов. Отсутствие проекта нормативов образования и размещения отходов увеличит экологические штрафы в пять раз. Экоплатежи за негативное воздействие на окружающую среду могут быть весьма высокими, что сделает нерентабельной деятельность предприятия. Кроме того, для компаний, которые уклоняются от выплаты такой компенсации, предусмотрены весьма крупные штрафы за экологические нарушения. Причем подвергнуться подобным санкциям можно и за неправильное оформление тех или иных документов.

Любое изъятие денежных средств из оборота организации в виде налоговых платежей в частности экологических может повлиять на финансовое состояние организации. Экономи- ческий субъект должен принять эффективные управленческие решения такие как например методическое обеспечение рейтинговой оценки финансового состояния предприятия.

Главной целью деятельности любого предприятия является стабильная и рентабельная работа, обеспечивающего устойчивое развитие с целью своевременного выполнения обязательств перед персоналом, партнерами и государством. Такой деятельности способствует проведение объективного финансового анализа, в процессе которого выбираются и оцениваются показатели, используемые для принятия обоснованных хозяйственных и финансовых решений с учетом специфики деятельности предприятия. Оценка, полученная в результате аналитической работы, должны быть произведена с позиции соответствия показателей нормативным (целевым) значениям.

Обоснование управленческих решений в экономической сфере невозможно без широкого использования информации о финансовом состоянии предприятий, которая получается в результате применения различных способов и приемов анализа. Однако в настоящее время актуальным становится использование комплексного подхода при оценке финансового состояния предприятия. В отечественной практике финансового анализа комплексный подход выражается такой терминологией как рейтинговая (комплексная, интегральная) оценка.

Целью рейтинговой оценки финансового состояния предприятия является получение важной для руководства о фактических результатах деятельности с возможностью определения тенденции (тренда) развития и получения прогнозных оценок на перспективу. Рейтинговая оценка связана с учетом все важнейших параметров (показателей) хозяйственной деятельности предприятия. Отбор системы показателей хозяйственной деятельности должен осуществляться исходя из потребностей пользователей в аналитической оценке. Преимуществом рейтинговой оценки является возможность четкого ранжирование целого ряда показателей по выбранным признакам.

По мнению известного экономиста Ковалева В.В. под рейтингом можно понимать выстраивание показателей в определенном порядке по заранее установленным правилам и критериям [6]. 
Выделяют два типа рейтингов [7]:

1. Упорядоченный рейтинг, который подразумевает ранжирование по убыванию или возрастанию какого-либо конкретного показателя. Минус данного метода заключается в затруднительном отборе финансовых показателей.

2. Классификационный рейтинг, который определяет, к какому из выделенных классов, можно отнести рассматриваемое предприятие.

Исследование показывает, что в наше время предложено немало методик рейтинговой оценки финансового состояния предприятия, каждая из которых отличается целями оценки, набором исходных показателей, степенью применения автоматизированных баз данных, алгоритмами получения стандартизированных показателей, свертки критериев и расчета рейтинговой оценки.

Николаевой В.Е. предложена балльнорейтинговая методика оценки финансового состояния предприятия с включением показателей ликвидности и платежеспособности, сравнением их фактических значений с нормативными уровнями. Методика позволяет рассчитывать баллы и проводить ранжирование деятельности предприятия по годам анализируемого периода или выполнять сравнительный анализ финансового состояния ряда предприятий [10].

По методике Кувшинова Д.А. и Половцева П.И. рейтинговая оценка финансового состояния предприятия проводится на основе выделения классов критериального уровня показателей финансового состояния предприятия. Это позволяет значение каждого показателя отнести к определенному классу и в дальнейшем рассчитать показатель рейтинговой оценки, который будет отражать уровень финансового состояния предприятия [7].

Коэффициенты, используемые при проведении рейтинговой оценки, должны нести в себе максимальное количество информации; для всех показателей должен быть числовой норматив минимального удовлетворительного уровня, а также показатели должны проводить оценку, как в пространстве, так и во времени.

Среди методик оценки рейтинговой оценки финансового состояния присутствуют как отечественные, так и зарубежные методики. По мнению некоторых ученых показатели платежеспособности и ликвидности являются основным критерием оценки финансового состояния организации.
Отнесение «экологических» платежей на счета затрат зависит от вида деятельности вашей организации (источника возникновения расходов, связанного с конкретной деятельностью), т.е. в бухгалтерском учете плата за негативное воздействие на окружающую среду будет признаваться расходом по обычным видам деятельности и включаться в состав расходов в полном объеме как в пределах, так и сверх нормативов с отражением по дебету счета $20(26,44)$ соответственно.

При наличии сверхнормативных платежей за загрязнение окружающей среды целесообразно к счетам учета затрат $(20,26,44)$ открыть субсчета:

- «Плата за загрязнение в пределах допустимых нормативов»;

- «Плата за загрязнение сверх допустимых нормативов».

Тогда при расчете налога на прибыль можно будет воспользоваться данными бухгалтерского учета, поскольку платежи за сверхнормативные выбросы загрязняющих веществ в окружающую среду не учитываются при определении налоговой базы по налогу на прибыль (п. 4 ст. 270 НК РФ), в то время как платежи за предельно допустимые выбросы, сбросы загрязняющих веществ, размещение отходов для целей исчисления налога на прибыль включаются в состав материальных расходов в пределах утвержденных лимитов (пп. 7 п. 1 ст. 254 НК РФ).

Таким образом, при наличии сверхнормативных платежей за загрязнение окружающей среды в бухгалтерском и налоговом учете будут возникать постоянные разницы. В соответствии с п. 4 Положения по бухгалтерскому учету «Учет расчетов по налогу на прибыль» ПБУ 18/02, утвержденного Приказом Минфина России от 19.11.2002 № 114н, образуется расход, уменьшающий только бухгалтерскую прибыль, и в бухгалтерском учете необходимо отразить постоянное налоговое обязательство, исчисляемое как произведение суммы платы за сверхнормативные выбросы (величина постоянной разницы) на ставку налога на прибыль.

Проводки: Дебет 99, субсчет «Постоянное налоговое обязательство», Кредит 68 - отражено постоянное налоговое обязательство.

Что касается кредитовой статьи отнесения «экологических» платежей в бухгалтерском учете, то здесь можно исходить из того, что они обязательны, но не относятся к налоговым платежам, 
предусмотренным ст. ст. 13-15 НК РФ. Следовательно, начисление указанной платы может отражаться в бухгалтерском учете на специально открываемом субсчете счета 76 «Расчеты с разными дебиторами и кредиторами». Вместе с тем, «экологические» платежи перечисляются в бюджет и им присвоен КБК, поэтому допускается учитывать их сумму на счете 68 «Расчеты по налогам и сборам».

Имеем бухгалтерские записи: Дебет 20 (26, 44) Кредит 68 (76 субсчет «Расчеты по плате за загрязнение окружающей среды») - начислена плата за загрязнение.

Помимо законотворчества необходима система административных и экономических мер воздействия на природопользователей имеющих просроченную задолженность по платежам в бюджет за пользование природными ресурсами.

Минфин России представил законопроект, который переведет экологический сбор в раздел налоговых платежей. Сделать это ведомство намерено с 2020 года. Принципиально новых платежей для бизнеса не возникнет, но теперь их станет администрировать ФНС, у которой больше инструментов для выявления уклонистов и взыскания задолженностей.

Сейчас существуют платы за негативное воздействие на окружающую среду. Минфин России отмечает, что платеж имеет «квазиналоговый характер» и отсутствие такого сбора в Налоговом кодексе РФ приводит к отсутствию единообразия применения неналоговых платежей и их эффективного администрирования. Поэтому Минфин РФ предлагает утвердить новую главу Налогового кодекса РФ и создать вместо таких платежей экологический налог. Его должны уплачивать организации, индивидуальные предприниматели и физические лица, если их хозяйственная деятельность негативно воздействует на окружающую среду или если в итоге образовались отходы.

Сейчас эти платежи администрирует Росприроднадзор, Минфин признает - взыскивать задолженности по платежам можно в судебном порядке, но «способы обеспечения исполнения обязанности по уплате фактически отсутствуют».

В рамках действующего законодательства у плательщиков отсутствует должная мотивация к правомерному поведению в форме уплаты платы за негативное воздействие на окружающую среду.
Теперь проблему решать будут с помощью Федеральной налоговой службы - ранее переход под администрирование налоговой в разы увеличил сборы в страховые фонды (переход перешел в 2017 году).

Налогоплательщики будут вставать на учет по месту нахождения объекта, который негативное воздействие оказывает в течение 30 дней с момента его постановки на государственный учет.

Налоговую базу плательщик будет определять самостоятельно по каждому объекту, для этого в законе прописана таблица на сотни наименований и стоимость на каждую тонну загрязняемых объектов. Например, тонна, загрязненная этанолом «стоит» 73553 руб., а свинцом - 99172 руб. Оплата такого налога будет проходить авансовыми платежами в размере одной четвертой части суммы налога, уплаченной за предыдущий год.

«С введением экологического налога режим взимания будет такой же, как у других налогов, поэтому собираемость значительно повысится. Поскольку собираемость повысится, фактическая нагрузка на бизнес тоже повысится, хотя номинально она останется прежней»,- резюмирует В. Зарипов.

На пленарном заседании Национального лесного форума в Москве подвели итоги работы саммита, в резолюцию которого вошли предложения со всех регионов, в которых прошел форум, а также профсоюзов и общественных организаций.

Председатель комитета по природным ресурсам, собственности и земельных отношений Госдумы РФ Николай Николаев в своем итогом выступлении отметил, что самый сложный путь - изменить систему управления лесами и лесным комплексом. «Необходимо изменить подход и создать единую информационную среду для всей отрасли. Мы сейчас точно не знаем, сколько у нас лесов, мы приняли решение, что передадим функции лесоустройства на федеральный уровень. Но этого не произошло. Необходимо зарегистрировать все пункты отгрузки и переработки древесины. На федеральном уровне этот вопрос необходимо решать. Можно сколько угодно ставить препятствий незаконной вырубке леса, но если есть «дыры» в законодательстве, то ими будут пользоваться. О фиксации транспортировки и продажи древесины мы говорим с 2016 года. Вопрос биржевой торговли, 
часть регионов уже перешли к торговле лесом на бирже, но необходимо узаконить биржевую торговлю на федеральном уровне,- заявил Николай Николаев.

Он также отметил и о важных предложениях, прозвучавших от профсоюзов. «Изменений можно добиться, только изменив систему управления лесами и лесным комплексом»,- заявил депутат Госдумы.

На пленарном заседании Национального лесного форума в Москве поднимался вопрос биржевой торговли лесом и создания российской национальной системы лесной сертификации. Оба эти инструмента должны привести к росту законного оборота древесины.

Как отметила в своем выступлении вицепрезидент Национальной ассоциации лесопромышленников «Русский лес» Маргарита Ли, на региональном форуме в Красноярске эта тема обсуждалась очень широко, но остался открытым вопрос: «зачем нам необходима своя национальная система лесной сертификации?».

По словам Ли, национальная система есть во всех лесных странах мира, но ее нет в России, хотя наша страна обладает 20\% мирового запаса лесного фонда. «Наша задача создать российскую национальную систему лесной сертификации, собрав лучший мировой опыт»,- заявила Маргарита Ли.

Николай Николаев добавил, что после форума в Красноярске тема создания национальной системы обсуждалась на Восточном экономическом форуме: «Я встречался с представителями японского и китайского бизнеса, и они выразили готовность войти в состав рабочей группы по разработке системы сертификации».

Продолжил тему создания прозрачных методов торговли лесом президент Санкт-Петербургской Международной Товарно-сырьевой биржи Алексей Рыбников. В своем докладе он отметил, что биржевая торговля лесом набирает популярность. По его словам, 24 региона России уже подписали соглашение с биржей, и в работу включаются всё новые регионы. «В регионах, где власти ведут активную работу, мы видим конкретные результаты. Так, например, те решения, которые были приняты властями Красноярского края в прошлом году, позволили региону в 2019 году выбиться в лидеры»,- сказал президент СПбМТСБ, отметив в том числе высокие результаты Удмуртии, а также Дальнего Востока и, в частности, Хабаровского края.
В рамках Национального лесного форума прошел семинар «Цифровизация природопользования», на котором Пермский край представил свой опыт выявления преступлений природоохранной направленности с помощью космического дистанционного мониторинга участникам форума из других регионов страны.

Цифровизация в лесной отрасли - ключ к снижению числа нарушений лесного законодательства, в том числе незаконных рубок и незаконного оборота древесины (использование спутниковых технологий и систем). «На примере Пермского края можно оценить применение данных космического мониторинга для выявления и доказывания преступлений, правонарушений природоохранной направленности. Для этого берутся различные даты космо-снимков разных лет. Это позволяет видеть, как изменяется ситуация, чаще чем раз в год. Именно с такой периодичностью проводится дистанционный мониторинг Рослесхоза»,- отмечает председатель Комитета по правовому обеспечению Ассоциации судебных экспертов Сибири и Дальнего Востока Юлия Саенко. Опыт проведения космического мониторинга в Пермском крае доказывает его высокий профилактический эффект. Дистанционный мониторинг в Прикамье на сегодня охватывает 700 тыс. га. (в случае непрерывного мониторинга снимки анализируются 1 раз в месяц, оперативного -1 раз в 2 недели). На всей этой территории в прошлом году было выявлено всего две незаконные рубки, в то время как в 2017 году, до проведения мониторинга, объем незаконной вырубленной древесины на этих территориях составлял более 20\% от всего объема. Рослесхоз на 2019 год увеличил площадь традиционного дистанционного мониторинга лесов в Прикамье (снимки анализируются 1 раз в год) в 1,5 раза доведя ее до 6,8 млн. га, что составляет около 60\% от общей площади земель лесного фонда на территории края. Для сравнения в целом в Приволжском федеральном округе мониторингом будет охвачено всего 10 млн. га. Комплексное применение на территории Пермского края всех видов дистанционного мониторинга (традиционного, непрерывного и оперативного) позволит выявить существенное число ранее совершенных незаконных рубок и обеспечить значительный профилактический эффект. Кроме того, в лесной отрасли большое внимание уделяется перспективам создания единого цифрового пространства, обеспечивающего 
управление отраслью и взаимодействие всех участников лесных взаимоотношений. Опытом применения информационных технологии в лесном хозяйстве поделился представитель лесного комплекса Иркутской области Дмитрий Ведмич. Система «Лесрегистр» применяется в министерстве лесного комплекса Иркутской области и его территориальных подразделениях - лесничествах для ведения реестра пунктов, формирования и ведения электронного архива и базы данных, содержащей информацию о принятой, переработанной и отгруженной древесине пунктами, формирования отчетных форм для анализа деятельности пунктов, приемки уполномоченным органом отчетных документов, предоставляемых пунктами. Кроме того, «умные» технологии в Пермском крае существенно сократили сроки выявления пожаров. Участникам форума продемонстрировали работу системы стационарного видеонаблюдения «Лесохранитель», которая позволяет своевременно обнаруживать лесные пожары и возгорания на прилегающих к лесам территориях. Сейчас система включает 10 видеокамер, с помощью которых ведется мониторинг территории лесного фонда площадью 770 тыс. га. В этом году планируется установить дополнительно 15 камер на вышках сотовой связи, что позволит непрерывно наблюдать за лесопожарной ситуацией на площади 1,7 млн. га. «Современный подход к организации получения, анализа и обмена оперативной информации о лесопожарной обстановке на территории лесного фонда Пермского края, с использованием внедрённых систем, позволит диспетчеру РДС грамотно, корректно и своевременно реагировать на вновь поступающе в РДС сообщения о потенциальных очагах и принимать действенные меры по организации тушения лесных пожаров»,- отмечает директор Пермского лесопожарного центра Игорь Старцев

На форуме Г. Клименко, член Совета ТПП РФ по цифровой экономике, А. Устименко, партнер EY, Г. Данилина, директор по маркетингу Dassault Systemes и А. Филатов, генеральный директор SAP СНГ обсудили цифровизацию городской среды и о практике реализации и перспективах развития. Более того, эксперты из лаборатории «Касперского» и «Softline» обсудили цифровизацию систем безопасности. В 2018 году Москва заняла первое место в рейтинге ООН, как город с самой эффективной системой предоставления электронных административных услуг органов исполнительной власти. Американский институт McKinsey, в свою очередь, обозначил Москву лучшим городом в Европе, предоставляющим своим горожанам новейшие городские технологии. И путей развития в программе «Умный город» еще множество.

Экологический сбор - это часть института расширенной ответственности производителей (РОП), который подразумевает, что выпустившее товар предприятие должно отвечать за утилизацию отходов, образовавшихся от него (преимущественно это упаковка). РОП дает три опции производителю: заплатить экологический сбор за утилизацию упаковки, заключить договор с подрядчиком на обработку мусора или организовать процесс самостоятельно.

Смысл РОП - стимулировать товаропроизводителей больше вовлекать образованные ими отходы обратно в экономику и меньше платить экосбор. По мнению Минфина, перевод экосбора в налог увеличит его собираемость, причем соответствующий законопроект в целом разработан и может вступить в силу с 1 января 2020 года или позднее.

Ставка экологического сбора должна расти, чтобы строительство мусороперерабатывающих мощностей и заключение договоров с операторами было выгоднее для производителей товаров, чем просто заплатить.

Помимо увеличения ставки экосбора планируется последовательное увеличение норматива утилизации, т.е. доли товара, облагаемого экосбором. Норма утилизации упаковки и пластиковой тары для производителей в 2015 году, когда РОП запустили, равнялась нулю, на следующий год она составила 5\% от произведенного, в 20172018 годах - 10\%, в 2019 году увеличится до 15\% и в перспективе должна постепенно дойти до 100\%. Представители перерабатывающей отрасли считают, что эта арифметическая прогрессия слишком медленная, а производители товаров, опасаясь резкого роста цен, не согласны с этой точкой зрения.

Экологическая политика РФ направлена на повышение экологической безопасности. Практика показывает, что принципы, сформулированные Концепцией перехода РФ к устойчивому развитию и Экологической доктриной, не реализуются в полном объеме. Основной проблемой является отсутствие механизма разграничения функций управления между федеральными и региональными органами государственной власти. 
Также не определен порядок взаимодействия органов исполнительной власти на всех уровнях, встречается дублирование функций. Нет четкой инструкции по проведению таких мероприятий как государственный экологический контроль, экологическая экспертиза, нормирование и пр.

Основные рыночные категории (рентабельность, цена, прибыль) не всегда применимы к экологической составляющей экономики. Многие экологические программы, принимаемые в стране, были направлены на достижение экономического эффекта, а не на формирование «экологического» мышления. А развитие производства на основе экстенсивного типа привело к уменьшению природных ресурсов и неизменности технологий производства без ориентации на экологическую составляющую. Хозяйственная деятельность с позиций экономики носила компенсационный характер (если производство не загрязняет окружающую среду, то минимальное количество платежей или их полное отсутствие, и наоборот, вредное производство - высокие платежи). Изменение подхода к решению экологических проблем - ключевая задача проводимой государством экологической политики. Загрязнители окружающей среды должны принять на себя ответственность за причиненный экологический ущерб. Это касается как производителей, так и население.

Принимаемые меры вынуждают предпринимателей соблюдать экологическую безопасность, инвестировать в экологические проекты в области технологического перевооружения для повышения конкурентоспособности. А применение ресурсосберегающих технологий положительно влияет на финансовый результат деятельности.

Государство предлагает различные механизмы для экономического стимулирования реализации природоохранных мероприятий (меры, которые поддерживают инвестиции на федеральном и региональном уровне, специальные инструменты развития поддержки и взаимодействия государства с инвестором). Необходимость решения экологических проблем была отражена Президентом РФ в Указе от 07.05.2017 № 204 «О национальных целях и стратегических задачах развития Российской Федерации на период до 2024 года». Для его исполнения приняты и реализуются национальный проект «Экология», «Стратегия экологической безопасности
РФ на период до 2025 года», «Стратегия развития промышленности по обработке, утилизации и обезвреживанию отходов производства и потребления на период до 2030 года». Все эти меры должны реализовываться на балансе интересов государства и бизнеса, который достигается через государственные гарантии, компенсации, поддержку малого предпринимательства, субсидии и пр.

На федеральном уровне государственная поддержка инвестиций в природоохранные и экологические мероприятия осуществляется через:

1. Налоговые льготы, которые являются основной составляющей государственной экологической политики.

2. Компенсационные выплаты (заключаются в возврате средств, направленных на проведение научных разработок в области природоохранной деятельности).

3. Инвестиционные налоговые кредиты (изменение срока уплаты налога, кредит может быть предоставлен по налогу на прибыль организации, а также по региональным и местным налогам).

4. Льготные условия пользования природными ресурсами (например, лесных земель или земель сельскохозяйственного назначения).

5. Льготное кредитование (на цели расширения производства при условии применения ресурсосберегающих или экологически безопасных технологий).

На региональном уровне государственная поддержка инвестиций в природоохранные и экологические мероприятия осуществляется через:

1. Предоставление субсидий (например, на возмещение части затрат на создание инфраструктуры, инженерных систем при реализации инвестиционных проектов, направленных на улучшение экологической обстановки).

2. Возврат лизинговых платежей (какойлибо их части) или затрат, связанных с приобретением оборудования.

3. Льготы по транспортному налогу и пр.

Государственная поддержка нефинансового характера заключается в создании экологических технологических и индустриальных парков, расширенной ответственности производителей и импортеров товаров за утилизацию отходов. 


\section{Библиографический список}

1. Конституция Российской Федерации (принята 12.12.2003). - М.: Закон, 2006.

2. Налоговый кодекс РФ. Часть I и II

3. Федеральный закон РФ от 10.01.2002. № 7-ФЗ. Закон «Об охране окружающей среды» / Электронный реcypc: www.consultant.ru.

4. Альтернативные источники энергии на предприятиях отрасли. Режим доступа: http://www.piterbell.ru/ alternativnye-istochnik-energii. htm

5. Горячева, О.П. Экспресс-аудит бухгалтерской (финансовой) отчетности коммерческих организаций: методические указания / О.П. Горячева, О.В. Конева; Краснояр. гос. торг.-экон. ин-т. - Красноярск, 2010.- 81 с.

6. Ковалев, В.В. Финансы организаций (предприятий): учебник / В. В. Ковалев. - Москва: Проспект, 2013. - 352 c.

7. Кувшинов Д.А., Половщев П.И. Рейтинговая оценка финансового состояния предприятия // Экономический анализ: теория и практика. 2007. № 6. С. 25-28.

8. Лукьянчиков Н.Н., Потравный И. М. Экономика и организация природопользования: учебник для студентов высших учебных заведений, обучающихся по направлению 521600 «Экономика»: научная специальность 08.00.05 «Экономика и управление народным хозяйством (Экономика природопользования): Москва. ЮНИТИ 2010, 687 с.

9. Малькова Т.М. Инновационное развитие предприятий лесопиления и деревообработки / Т.М. Малькова, Д.С. Шлычков // Инновационное развитие экономики.- Йошкар-Ола, Научно-консалтинговый центр.№ 1(18). - 2014.- С. 64-70.

10. Николаева В.Е. Классификация организаций по уровню их финансового состояния // Российское предпринимательство. 2012. № 17. С. 59-65.

11. Об оздоровлении экологической обстановки в Российской Федерации. Режим доступа: http://www.regnum. ru/allnews/123206.html\#ixzz14990wg8d

12. «Основы государственной политики в области экологического развития Российской Федерации на период до 2030 года» (утв. Президентом РФ 30.04.2012)/ Электронный ресурс: www.consultant.ru.

13. Проблемы изъятия рентных доходов. Режим доступа: http://www.xserver.ru/user/prird/

14. Экологическая доктрина Российской Федерации.- Москва, 2002.

15. http://www.r11. nalog.ru/ - Управление ФНС по республике Коми.

16. Ковалев, В.В. Финансы организаций (предприятий): учебник / В.В. Ковалев.-Москва: Проспект, 2013. - 352 c.

17. Кувшинов Д.А., Половщев П.И. Рейтинговая оценка финансового состояния предприятия // Экономический анализ: теория и практика. 2007. № 6. С. 25-28. 